\title{
CORRESPONDENCE
}

\section{Landing on Mars}

SiR,--After more than a year of arduous study, the Viking landing site selection team has chosen four tentative landing sites on Mars for the summer of 1976, when it is hoped two NASA Viking landers will be set down on the planet. These locales were chosen with considerable attention to site safety and likely scientific return. As a participant in the selection team I can attest that a wide range of alternative views were considered in a very open manner. Our ability to predict surface properties on an unexplored planet, however, using photographs with at best 100 metre resolution, is clearly limited. The prime and backup sites for the $\mathrm{A}$ and $\mathrm{B}$ landers are as follows: A1 $\left(19.5^{\circ} \mathrm{N}, 34^{\prime \prime}\right.$ W): Chryse; A2 $\left(20^{\circ} \mathrm{N}, 252^{\circ} \mathrm{W}\right)$ : Tritonis Lacus; B1 $\left(44.3^{\circ} \mathrm{N}, 10^{\circ} \mathrm{W}\right)$ : Cydonia ; B2 $\left(44.2^{\circ} \mathrm{N}, 110^{\circ} \mathrm{W}\right)$ : Alba.

It is of interest to imagine the circumstances reversed, and four landing sites with precisely these planetocentric coordinates chosen on the planet Earth for investigation by hypothetical spacecraft from somewhere else. The comparable landing sites are these: $\mathrm{Al}$ $\left(19.5^{\circ} \mathrm{N}, 35^{\circ} \mathrm{W}\right)$ : Atlantic Ocean, Cape Verde Basin ; A2 (20 $\left.\mathrm{N}, 108^{\circ} \mathrm{E}\right)$ : Gulf of Tonkin, $0.2^{\circ} \mathrm{S}$ of Nightingale I.; B1 $\left(44.3^{\circ} \mathrm{N}, 10^{\circ} \mathrm{W}\right)$ : North Atlantic, $9^{\circ} \mathrm{W}$ of Mimizan (near Bordeaux); B2 $\left(44.2^{\circ} \mathrm{N}, 110^{\circ} \mathrm{W}\right)$ : Wyoming, SE corner of Yellowstone National Park.

Corresponding nicely to the ratio of water to land area on the planet Earth; we see that three of the four landing sites are in the ocean. While occasional events may be detected during a short stay in some of these places-site Al is in the Canary Current used by 16 th century sailing vessels travelling to the "New World", and naval activity is not entirely unknown in the Gulf of Tonkin - the probability of encountering such events during a brief flotation would be low. But site B2 is near a tributary of the Yellowstone River, adjacent to some of the most spectacular geology and most interesting biology on our planet.

It is sobering to imagine the picture of the planet Earth that would be com. municated to a space-faring society on another planet after a brief inspection of these locales. Were two spacecraft to be landed in sites $\mathbf{A} 1, \mathbf{A} 2$, or $\mathbf{B} 1$, they would probably sink out of sight into the ocean and probably never be noticed by the inhabitants of the planet Earth. The B2 site would be rather unrepresentative of the geology of the
Earth, but would provide a substantial chance of detecting indigenous life and a better than average chance of detecting intelligent life. A reasonable strategy of extraterrestrial exploration of the Earth-noting the separation of surface features into "bright" and "dark" areas-might be to land one spacecraft at Yellowstone and the other in the Atlantic Ocean. Yellowstone might be selected because of its apparent high interest at 100 metre resolution for geologists and the Atlantic Ocean might be chosen as "safe" because of its smooth appearance at 100 metre resolution.

If we imagine a Mars as heterogeneous as the Earth-and the Mariner 9 investigations surely point in this direction-the conclusion is clearly that more than a few landers are necessary for an adequate in situ characterization of the principal features of the Martian environment.

\section{Yours faithfully,} CARL SAGAN

Laboratory for Planetary Studies, Cornell University

\section{Entry to EMBO}

SIR,--.-The setting up of the European Molecular Biology Laboratory in Heidelberg (Nature, 243, 125; 1973) provides a splendid opportunity to bring together a group of stimulating and creative minds.

However, it is well known that scientists are at their most stimulating and creative before reaching the age of about 35, and if the staff of the EMBO laboratory are to be international, then this will impose a severe restriction on the number of non-British members. The reason for this is quite simple. Presumably the staff will be drawn from universities, and will require a $\mathrm{PhD}$ to conduct independent research. In this case, our average English molecular biologist would be around 25, but our fellow mainland European would be nearer 35.

This is not meant as an argument against cooperation. On the contrary, it is a plea to seize an opportunity to break down anachronistic barriers, and to spend the millions of dollars allocated to EMBO with more regard to a fertile rather than a sterile generation. Yours faithfully,

Lerchenrain 19 ,

H. J. LEESE

8046, Zürich

\section{Errata}

THE contents entry for the article "Mutual Antagonism between Botulinum Toxin and $\alpha$-Bungarotoxin" (Nature, 243, 166; 1973) is incorrect and should read "Toxins-Bacterial botulinum toxin and snake venom toxin $\alpha$-bungarotoxin act at different sites-. . .".

IN the article "Increased Yield through Correction of Sulphur Deficiency in Rycgrass Exposed to Sulphur Dioxide" by D. W. Cowling, L. H. P. Jones and D. R. Lockyer (Nature, 243, 479; 1973) the following correction should be made : paragraph 3 , line 11 , “... potassium simply as $\mathrm{KCl}$ plus $\mathrm{KH}_{2} \mathrm{PO}_{4}$ ".

\section{Announcements}

\section{International Meetings}

August 6-8, Thermophysical Properties. (Symposium Chairman, School of Mechanical Engineering and Thermophysical Properties Research Center, Purdue University, Lafayette, Indiana, USA 47906.)

August 13-16, Sixth Annual Meeting of the Society for Study of Reproduction. (Claude Cruse, 113 N. Neil Street, Champaign, Illinois 61820.)

August 13-17, 45th ANZAAS Congress. (Mrs Dulcie Stretton, ANZAAS Congress Executive Officer, University of Western Australia, Nedlands, W.A. 6009.)

August 14-16, Microwave Semiconductor Devices, Circuits and Applications. (Professor Lester F. Eastman, Cornell School of Electrical Engineering, Phillips Hall, Ithaca, NY 14850.)

August 15-17, 17th Canadian High Polymer Forum. (17th Canadian High Polymer Forum, Pharmaceutical Chemistry Division, Health Protection Branch, Tuney's Pasture, Ottawa, Ontario K1A OL2.)

August 19-23, The Role of the Cell Surface Interactions in Development and Differentiation. (VIIth International Congress, Department of Anatomy, University of Montreal, P.O. Box 6128, Montreal 101, Canada.)

August 19-24, Developmental Biology. (VIIth International Congress of Developmental Biology, c/o Department of Anatomy, University of Montreal, P.O. Box 6128, Montreal 101, Canada.) 